\title{
Milk fat responses to butterfat infusion during conjugated linoleic acid-induced milk fat depression in lactating dairy cows
}

\author{
D. Vyas, ${ }^{*}$ U. Moallem, $†$ B. B. Teter, ${ }^{*}$ A. R. K. Fardin-Kia, $\ddagger$ and R. A. Erdman*1 \\ *Animal and Avian Sciences Department, University of Maryland, College Park 20742 \\ †Department of Ruminant Science, Institute of Animal Sciences, Volcani Center, Bet Dagan 50250, Israel \\ $\ddagger$ Center for Food Safety and Applied Nutrition, Food and Drug Administration, College Park, MD 20742
}

\section{ABSTRACT}

During diet-induced milk fat depression (MFD), the short and medium-chain fatty acids (SMCFA), which are synthesized de novo in the mammary gland, are reduced to a much greater extent than the long-chain fatty acids (LCFA) that originate from the circulation. Our hypothesis was that increased availability of SMCFA might rescue conjugated linoleic acid (CLA)-induced MFD in lactating dairy cows. To test that hypothesis, 4 rumen-fistulated lactating Holstein cows $(128 \pm 23$ $\mathrm{d}$ in milk) were used in a $4 \times 4$ Latin square design with 3 -wk experimental periods. Treatments were applied during the last $2 \mathrm{wk}$ of each period and included $3 \times$ daily abomasal infusion of a total of (1) $230 \mathrm{~g} / \mathrm{d}$ of LCFA (blend of 59\% cocoa butter, $36 \%$ olive oil, and $5 \%$ palm oil); (2) $420 \mathrm{~g} / \mathrm{d}$ of butterfat (BF); (3) $230 \mathrm{~g} / \mathrm{d}$ of LCFA with $27 \mathrm{~g} / \mathrm{d}$ of CLA (LC-CLA), containing 10 $\mathrm{g} / \mathrm{d}$ of trans-10,cis-12 CLA; and (4) $420 \mathrm{~g} / \mathrm{d}$ of butterfat with $27 \mathrm{~g} / \mathrm{d}$ of CLA (BF-CLA). Butterfat provided $50 \%$ of $\mathrm{C} 16(115 \mathrm{~g} / \mathrm{d})$ and similar amounts of C18 FA as found in LCFA, such that the difference between the $\mathrm{BF}$ and LCFA treatments was $190 \mathrm{~g} / \mathrm{d}$ of SMCFA. No treatment effects were observed for DMI or milk yield. Milk fat content was reduced by 41 and $32 \%$, whereas milk fat yield was reduced by 41 and $38 \%$ with LCCLA and BF-CLA, respectively, compared with their respective controls. Abomasal infusion of CLA reduced de novo synthesized fatty acid (DNFA; SMCFA and 50\% C16:0) concentration, whereas DNFA tended to be greater with $\mathrm{BF}$ infusion. An interaction was observed between SMCFA and CLA as the increased availability of SMCFA reduced stearoyl-CoA-desaturase-1 gene expression, whereas it tended to reduce lipoprotein lipase ( $L P L)$, 1-acylglycerol-3-phosphate O-acyltransferase 6 (AGPAT-6), sterol regulatory element-binding protein cleavage-activating protein $(S C A P)$, and peroxisome proliferator-activated receptor $\gamma(P P A R-\gamma)$ gene ex-

Received June 21, 2012.

Accepted December 28, 2012.

${ }^{1}$ Corresponding author: erdman@umd.edu pression in the presence of CLA. The mRNA expression of genes involved in de novo fatty acid synthesis [acetyl-coenzyme A carboxylase $\alpha(A C A C A)$ and fatty acid synthase $(F A S N)]$, fatty acid uptake $(L P L)$, and triglyceride synthesis [AGPAT-6 and diacylglycerol Oacyltransferase 1 (DGAT-1)] along with protein abundance of the ACC and FASN were reduced with CLA. However, the increased availability of SMCFA had no effect on lipogenic gene expression except for $L P L$, whose expression was increased with $\mathrm{BF}$ infusion. The nutritional manipulation by increasing the intestinal availability of SMCFA was not sufficient to rescue CLA-induced MFD.

Key words: milk fat, de novo synthesis, fatty acid, dairy cow

\section{INTRODUCTION}

Milk fat synthesis depends on 2 general sources of FA [i.e., de novo synthesis of FA in the mammary gland and transfer of preformed FA from blood triglycerides (TG)]. The short- and medium-chain FA (SMCFA; C4-C14) and half of C16 are synthesized de novo, whereas the rest of the FA including $50 \%$ of $\mathrm{C} 16$ and other long-chain FA (LCFA) are derived from TG in the blood or from NEFA mainly during negative energy balance (Jensen, 2002).

Milk fat synthesis is highly responsive to nutritional manipulation and nutrition has been used as a practical tool to alter milk fat yield and FA composition (Sutton, 1989). Certain dietary alterations, including highconcentrate diets and diets high in PUFA, can induce a low-milk fat syndrome, reducing milk fat percentage and yield up to $46 \%$, which is commonly referred to as milk fat depression (MFD; Piperova et al., 2000; Peterson et al., 2003). During MFD, mammary lipogenesis is inhibited by specific FA intermediates produced during rumen biohydrogenation (Bauman and Griinari, 2003). The relationship between trans-10, cis-12 conjugated linoleic acid (CLA) and MFD is well established (Baumgard et al., 2000). The infusion of trans-10,cis-12 CLA is accompanied by dramatic reduction in mRNA 
abundance of enzymes such as acetyl-CoA carboxylase $(\boldsymbol{A C C})$ and FA synthase $(\boldsymbol{F A} \boldsymbol{S N})$, which are involved in de novo FA synthesis; lipoprotein lipase $(\boldsymbol{L P} \boldsymbol{L})$ and FA-binding protein $(\boldsymbol{F A P B})$, which are associated with mammary uptake and intracellular transport of FA; stearoyl-CoA desaturase $(\boldsymbol{S C D})$, which desaturates FA; and 1-acylglycerol-3-phosphate O-acyltransferase $(\boldsymbol{A} \boldsymbol{G}$ $\boldsymbol{P A T}$ ) and diacylglycerol O-acyltransferase $(\boldsymbol{D} \boldsymbol{G A T})$, required for TG assembly (Piperova et al., 2000; Peterson et al., 2003). The coordinated downregulation of mammary lipogenic enzymes during MFD suggests a major role of transcription factors such as sterol regulatory element-binding protein $1(\boldsymbol{S R E B P}-\mathbf{1})$ on mammary lipogenesis (Harvatine and Bauman, 2006). During diet-induced MFD, the de novo synthesized SMCFA are reduced to a much greater extent than the LCFA that originate from circulating blood TG originating from the diet and tissue-mobilized TG (Chouinard et al., 1999; Baumgard et al., 2002).

The SMCFA are essential for formation of milk TG (Moore and Steele, 1968) and for maintaining the fluidity of milk fat (Barbano and Sherbon, 1980). Recently, the importance of SMCFA during milk fat synthesis was underscored when postruminal infusion of butterfat (BF), used as a source of SMCFA, increased milk fat secretion in lactating dairy cows by increasing the secretion of both SMCFA and LCFA (Kadegowda et al., 2008). This suggests that the mammary gland is responsive to SMCFA during normal milk fat synthesis. We hypothesized that the responsiveness to absorbed SMCFA would be greater when de novo synthesis of these FA is inhibited. Thus, the objective of the present study was to determine whether CLA-induced MFD could be reversed or prevented by SMCFA availability.

\section{MATERIALS AND METHODS}

\section{Animals, Experimental Design, Treatment, and Sampling}

All procedures for this experiment were conducted under a protocol approved by the University of Maryland (College Park) Institutional Animal Care and Use Committee (protocol no. R-09-95). Four rumenfistulated multiparous Holstein dairy cows in mid lactation $(128 \pm 23$ DIM) were used in a $4 \times 4$ Latin square design balanced for carryover effects. Treatments were abomasal infusion of the following: (1) 230 $\mathrm{g}$ of LCFA/d; (2) $420 \mathrm{~g}$ of BF/d; (3) $230 \mathrm{~g}$ of LCFA/d with $27 \mathrm{~g}$ of $\mathrm{CLA} / \mathrm{d}$, containing $10 \mathrm{~g}$ of trans-10, cis-12 $\mathrm{CLA} / \mathrm{d}$; and (4) $420 \mathrm{~g}$ of $\mathrm{BF} / \mathrm{d}$ with $27 \mathrm{~g}$ of CLA/d. The ingredient and chemical compositions of the basal diet are in Table 1.
Table 1. Ingredient and chemical composition of the basal diet

\begin{tabular}{|c|c|}
\hline Item & Amount \\
\hline \multicolumn{2}{|l|}{ Ingredient, $\%$ of $\mathrm{DM}$} \\
\hline Corn silage & 50.02 \\
\hline Corn grain, ground & 26.01 \\
\hline Soybean meal & 20.21 \\
\hline Corn gluten meal $(60 \%)$ & 0.45 \\
\hline Limestone & 0.62 \\
\hline Calcium phosphate & 0.43 \\
\hline Magnesium oxide & 0.16 \\
\hline Sodium bicarbonate & 0.57 \\
\hline Dynamate $^{1}$ & 0.13 \\
\hline Salt & 0.38 \\
\hline Trace minerals and vitamins ${ }^{2}$ & 0.46 \\
\hline Megalac $^{3}$ & 0.56 \\
\hline $\mathrm{DM}, \%$ & 60.88 \\
\hline \multicolumn{2}{|l|}{ Chemical composition, $\%$ of DM } \\
\hline $\mathrm{CP}$ & 16.69 \\
\hline $\mathrm{RUP}^{4}$ & 43.02 \\
\hline $\mathrm{ADF}$ & 16.98 \\
\hline NDF & 29.21 \\
\hline $\mathrm{Ca}$ & 0.81 \\
\hline $\mathrm{P}$ & 0.45 \\
\hline $\mathrm{Mg}$ & 0.32 \\
\hline $\mathrm{K}$ & 1.19 \\
\hline $\mathrm{Na}$ & 0.35 \\
\hline $\mathrm{Cl}$ & 0.41 \\
\hline $\mathrm{NE}_{\mathrm{L}},{ }^{5} \mathrm{Mcal} / \mathrm{kg}$ & 1.56 \\
\hline
\end{tabular}

${ }^{1}$ Mosaic Co., Plymouth, MN.

${ }^{2}$ Trace mineral and vitamin mix combined, which provided an additional $0.76 \mathrm{mg}$ of $\mathrm{Co} / \mathrm{kg}, 10 \mathrm{mg}$ of $\mathrm{Cu} / \mathrm{kg}, 5.5 \mathrm{mg}$ of Fe $/ \mathrm{kg}, 0.64 \mathrm{mg}$ of I $/ \mathrm{kg}, 37 \mathrm{mg}$ of $\mathrm{Zn} / \mathrm{kg}, 0.33 \mathrm{mg}$ of Se $/ \mathrm{kg}, 3,526 \mathrm{IU}$ of vitamin $\mathrm{A} / \mathrm{kg}$, $1,175 \mathrm{IU}$ of vitamin $\mathrm{D} / \mathrm{kg}$, and $22 \mathrm{IU}$ of vitamin $\mathrm{E} / \mathrm{kg}$ to the diet DM. ${ }^{3}$ Church \& Dwight Co. Inc., Princeton, NJ.

${ }^{4}$ Trace mineral and vitamin mix combined, which provided an additional $0.76 \mathrm{mg}$ of $\mathrm{Co} / \mathrm{kg}, 10 \mathrm{mg}$ of $\mathrm{Cu} / \mathrm{kg}, 5.5 \mathrm{mg}$ of $\mathrm{Fe} / \mathrm{kg}, 0.64 \mathrm{mg}$ of I $/ \mathrm{kg}, 37 \mathrm{mg}$ of $\mathrm{Zn} / \mathrm{kg}, 0.33 \mathrm{mg}$ of Se $/ \mathrm{kg}, 3,526 \mathrm{IU}$ of vitamin $\mathrm{A} / \mathrm{kg}$, $1,175 \mathrm{IU}$ of vitamin $\mathrm{D} / \mathrm{kg}$, and $22 \mathrm{IU}$ of vitamin $\mathrm{E} / \mathrm{kg}$ to the diet DM. ${ }^{5}$ Calculated value based the estimated TDN from feed analysis at $3 \times$ maintenance intake using NRC (2001) prediction equations.

The LCFA mixture was a blend of $59 \%$ cocoa butter (Bloomer Chocolate Co., Chicago, IL), 36\% olive oil (Filippo Berio, Hackensack, NJ), and $5 \%$ palm oil (Malaysian Palm Oil Board, Washington, DC). In the BF treatment, butter oil was prepared from commercially available unsalted butter (Kirkland Signature; Costco Wholesale Corp., Seattle, WA) melted at $37^{\circ} \mathrm{C}$ and separated from the protein coagulate by filtration. The commercial liquid CLA mixture (Clarinol; Stepan Lipid Nutrition, Maywood, NJ) was used for abomasal infusion of CLA isomers. Amounts of postruminally infused individual FA in the LCFA mixture and BF are shown in Figure 1. The FA composition of the fat supplements is presented in Table 2 .

Experimental periods were 3 wk. The first wk of each period was without fat infusion to reduce carryover effects. This was followed by 2 wk of abomasal infusion as used in the previous study (Kadegowda et al., 2008). Fat supplements were infused into the abomasum us- 


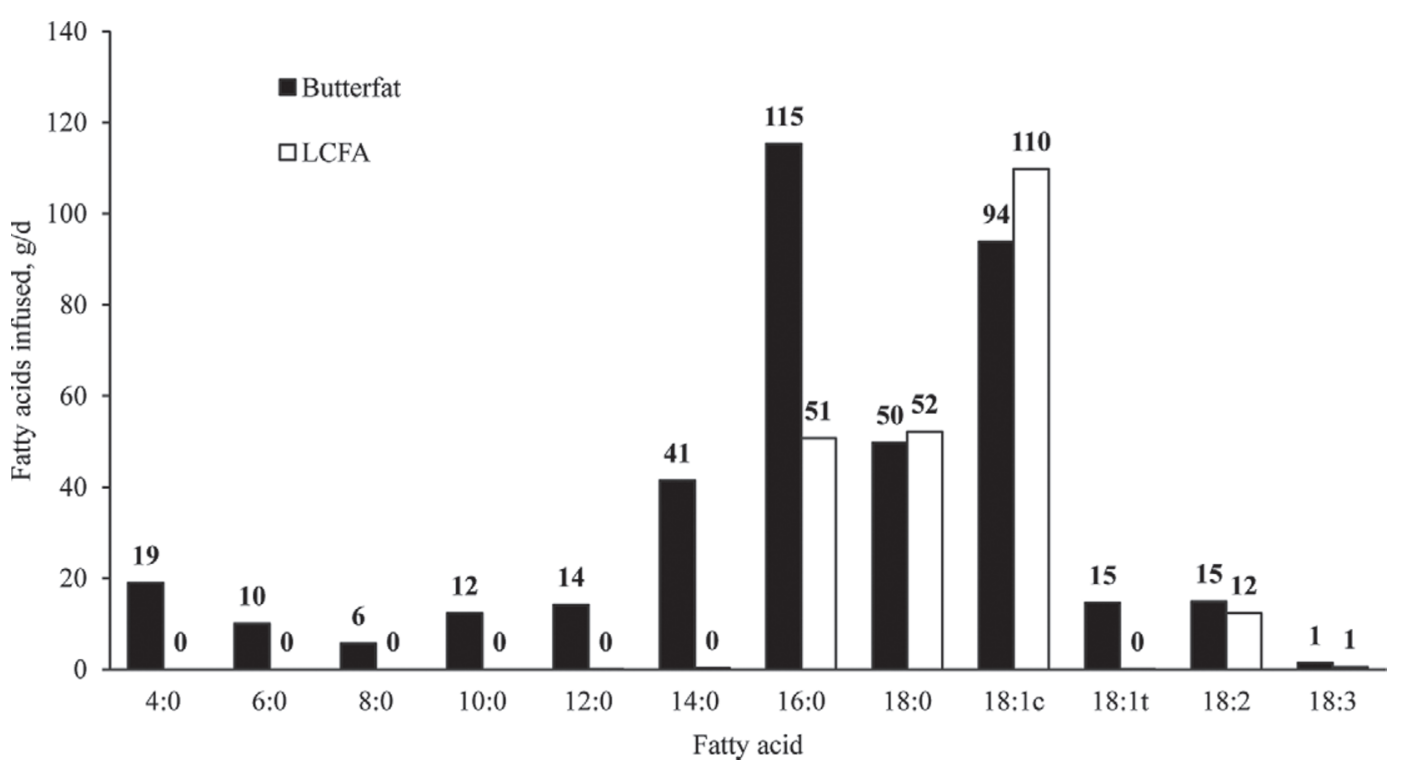

Figure 1. Fatty acid composition of abomasally infused butterfat and long-chain FA (LCFA). $\mathrm{c}=$ cis; $\mathrm{t}=$ trans.

ing procedures previously described by Kadegowda et al. (2008). The fat mixtures were liquefied at $37^{\circ} \mathrm{C}$ in a warming oven and mixed well before infusion. The amount of each FA mixture was divided into equal portions and manually infused 3 times per day (140 g of butterfat, $76.6 \mathrm{~g}$ of LCFA, and $9 \mathrm{~g}$ of CLA at 0800, 1400, and $1900 \mathrm{~h}$ ). Actual amounts of infused fat were recorded daily. Patency and location of the infusion line in each cow were checked on alternate days.

Cows were housed in individual tiestalls equipped with rubber mats and bedded with wood shavings. Cows were fed a basal diet containing $50 \%$ forage and $50 \%$ concentrate (DM basis) to meet NRC (2001) nutrient specifications for a $600-\mathrm{kg}$ cow producing $45 \mathrm{~kg}$ of milk containing $3.7 \%$ milk fat and $3.1 \%$ milk protein. Diets were fed as TMR once daily at $0800 \mathrm{~h}$. Forage and ingredient DM were measured weekly, and the TMR was adjusted accordingly to maintain a constant forage-to-concentrate ratio on a DM basis. Amounts of feed offered and refused were recorded once daily. Cows were milked twice daily at 0700 and $1700 \mathrm{~h}$, and milk production was recorded electronically at each milking. Samples for milk composition and FA analysis were collected from the last 6 consecutive milkings during wk 3 of each experimental period. Milk fat, protein, and SCC were determined by infrared analysis (MilkoScan; Foss Food Technology Corp., Eden Prairie, MN) on fresh samples from individual milkings. A subset of samples from each milking was composited and frozen at $-20^{\circ} \mathrm{C}$ for subsequent FA analysis. Transfer efficiency of each FA was calculated as the increased output in milk divided by the infused FA.

\section{Milk FA Analysis}

Milk FA composition was analyzed from pooled milk samples from last 6 consecutive milkings of $\mathrm{wk}$ 3. The FA methyl esters (FAME) were prepared by mild transesterification with $1.4 \mathrm{~mol} / \mathrm{L}$ of $\mathrm{H}_{2} \mathrm{SO}_{4}$ in methanol (Christie, 1982). Separations were achieved using an Agilent $6890 \mathrm{~N}$ gas chromatograph (Agilent Technologies Inc., Wilmington, DE) equipped with a flame ionization detector. Hydrogen was used as the carrier gas at $1 \mathrm{~mL} / \mathrm{min}$ constant flow with a linear velocity of $30 \mathrm{~cm} / \mathrm{s}$. Air flow was maintained at 400 $\mathrm{mL} / \mathrm{min}$. Nitrogen was used as make up gas at a flow rate of $33 \mathrm{~mL} / \mathrm{min}$. The oven was maintained at $169^{\circ} \mathrm{C}$ isothermal temperature, the injection port at $250^{\circ} \mathrm{C}$, and the detector at $250^{\circ} \mathrm{C}$. The split ratio was set to 1:100 and the typical injection volume was $1 \mu \mathrm{L}$.

The SMCFA were analyzed as FA butyl esters (FABE), which were mathematically converted to FAME and normalized to the FAME chromatogram (Gander et al., 1962). The original FABE procedure was modified as follows: milk samples were heated in screw-capped test tubes at $80^{\circ} \mathrm{C}$ for $1 \mathrm{~h}$ in the presence of $1.4 \mathrm{~N} \mathrm{H}_{2} \mathrm{SO}_{4}$ in butanol, and then extracted with hexane in the presence of saturated $\mathrm{KCl}$ and distilled water. Samples were then centrifuged at $500 \times g$ for 5 min at room temperature. Aliquots of the upper hexane layer were injected directly into a Hewlett-Packard 5880 gas-liquid chromatograph equipped with a split injector, a flame ionization detector and a $25-\mathrm{m} \times 0.2-$ $\mathrm{mm}$ i.d. fused silica capillary column coated with HP1 (Hewlett-Packard Co., Avondale, PA). Helium was used 
VYAS ET AL.

Table 2. Fatty acid composition of fat supplements infused in lactating dairy cows

\begin{tabular}{|c|c|c|c|c|c|c|}
\hline $\begin{array}{l}\text { FA, } \\
\mathrm{g} / 100 \mathrm{~g} \text { of } \mathrm{FAME}^{1}\end{array}$ & $\mathrm{CLA}^{2}$ & Butterfat & $\begin{array}{l}\text { Palm } \\
\text { oil }\end{array}$ & $\begin{array}{l}\text { Olive } \\
\text { oil }\end{array}$ & $\begin{array}{l}\text { Cocoa } \\
\text { butter }\end{array}$ & $\mathrm{LCFA}^{3}$ \\
\hline 4:0 & & 4.52 & & & & \\
\hline $6: 0$ & & 2.40 & & & & \\
\hline 8:0 & & 1.36 & & & & \\
\hline 10:0 & & 2.94 & & & & \\
\hline $12: 0$ & & 3.39 & 0.25 & & & 0.01 \\
\hline 13:0 & & 0.16 & & & & \\
\hline 14:0 & 0.03 & 9.87 & 1.06 & 0.03 & 0.11 & 0.13 \\
\hline $15: 0$ & & 1.48 & 0.05 & & 0.03 & 0.02 \\
\hline $14: 1$ & & 0.73 & & & & \\
\hline 16:0 & 0.18 & 27.46 & 41.15 & 13.82 & 25.25 & 22.06 \\
\hline $16: 1$ & 0.07 & 1.23 & 0.16 & 1.24 & 0.24 & 0.60 \\
\hline $17: 0$ & & 1.14 & 0.10 & 0.08 & 0.23 & 0.17 \\
\hline 18:0 & 0.07 & 11.85 & 4.16 & 2.65 & 36.40 & 22.59 \\
\hline $17: 1$ & & 0.19 & 0.03 & 0.12 & & 0.04 \\
\hline cis-9 18:1 & 5.26 & 21.12 & 40.82 & 69.12 & 32.83 & 46.41 \\
\hline cis-11 18:1 & 0.37 & 0.53 & 0.75 & 2.78 & 0.34 & 1.24 \\
\hline cis-12 18:1 & & 0.51 & 0.00 & & & \\
\hline cis-13 18:1 & 0.11 & 0.06 & 0.01 & & & \\
\hline cis-14 18:1 & & 0.05 & & & & \\
\hline total trans $18: 1$ & & 3.52 & & & & \\
\hline trans-11,cis-15 18:2 & 0.14 & 0.07 & 0.19 & 0.03 & & 0.02 \\
\hline cis-9,cis-12 18:2 & 0.79 & 2.98 & 10.26 & 8.61 & 2.91 & 5.26 \\
\hline $18: 3$ & & 0.34 & 0.18 & 0.42 & 0.17 & 0.26 \\
\hline $20: 0$ & 0.15 & 0.16 & 0.42 & 0.49 & 1.15 & 0.81 \\
\hline cis-9 20:1 & & 0.10 & 0.01 & 0.00 & & \\
\hline cis-11 20:1 & & 0.04 & 0.15 & 0.30 & 0.05 & 0.15 \\
\hline $20: 2$ & 1.18 & & & & & \\
\hline $22: 0$ & & 0.04 & 0.08 & 0.16 & 0.21 & 0.19 \\
\hline trans-7,cis-9 18:2 & & 0.04 & & & & \\
\hline cis-9,trans-11 18:2 & 42.55 & 0.47 & & & & \\
\hline cis-10,trans-12 18:2 & 0.89 & & & & & \\
\hline trans-9,cis-11 18:2 & 0.89 & & & & & \\
\hline cis-11,trans-13 18:2 & 0.73 & & & & & \\
\hline trans-10,cis-12 18:2 & 45.56 & & & & & \\
\hline $\mathrm{C} 20: 3$ & & 0.11 & & & & \\
\hline C20:4 & & 0.16 & & & & \\
\hline
\end{tabular}

${ }^{1}$ FAME $=$ FA methyl esters.

${ }^{2}$ Conjugated linoleic acid.

${ }^{3}$ Long-chain FA.

as the carrier gas at a flow rate of $2 \mathrm{~mL} / \mathrm{min}$, with a split ratio of 45:1. The injector temperature and detector temperature were set at $250^{\circ} \mathrm{C}$, whereas the column temperature started at $130^{\circ} \mathrm{C}$. The ramp was set at $6^{\circ} \mathrm{C} / \mathrm{min}$ to $190^{\circ} \mathrm{C}$, followed by $4^{\circ} \mathrm{C} / \min$ to $260^{\circ} \mathrm{C}$, and finally holding at $260^{\circ} \mathrm{C}$ for $20 \mathrm{~min}$. Standard mixtures, including GLC-60 (Nu-Chek Prep Inc., Elysian, MN), were converted to FABE to aid in the identification and quantification of FA (Vyas et al., 2012).

\section{Mammary Biopsy}

Mammary biopsies were performed on d 21 of each experimental period. Biopsies were taken from either the left or the right rear gland. The biopsy site was carefully selected to avoid larger subcutaneous blood vessels. Preparation of the site involved shaving and washing with dilute Betadine (The Purdue Frederick
Co., Stamford, CT) solution and sanitizing with ethyl alcohol $(70 \%)$. Cows were given intravenous Xylazine (0.50-0.70 mL; $20 \mathrm{mg} / \mathrm{mL}$; Bayer Animal Health, Shawnee, Kansas) before anesthetizing the biopsy site by subcutaneous injection of Lidocaine hydrochloride ( 5 $\mathrm{mL} ; 2 \%$ solution; Butler Animal Health, Dublin, $\mathrm{OH})$. An incision was made $(\sim 0.5-1.0 \mathrm{~cm})$ on the outside of the quarter using a scalpel blade (size 22) through the skin and underlying fascia to the point where the mammary gland capsule was clearly visible. This process was carefully conducted to ensure that the multiple layers of connective tissue were pulled aside and the mammary capsule was not punctured. A Bard Magnum core biopsy instrument (Bard Peripheral Vascular Inc., Tempe, AZ) with a Bard Magnum core tissue biopsy needle $(\mathrm{MN1210}, 12 \mathrm{G} \times 10 \mathrm{~cm})$ was used to biopsy mammary tissue (30-50 mg of tissue/biopsy). Any visible connective tissue was removed following biopsy and 
the mammary tissue samples were immediately frozen in liquid $\mathrm{N}_{2}$ and stored at $-80^{\circ} \mathrm{C}$.

\section{RNA Isolation and Quantitative Real-Time Reverse-Transcription PCR}

Frozen biopsy tissues were weighed $(\sim 30 \mathrm{mg})$ and immediately subjected to RNA extraction using a Qiagen RNeasy mini kit with on-column DNase digestion (Qiagen Inc., Valencia, CA). The RNA concentration and quality was measured using a NanoDrop ND-1000 spectrophotometer (Thermo Fisher Scientific, Wilmington, DE). The purity of RNA [ratio of absorbance at $260 \mathrm{~nm}$ to absorbance at $\left.280 \mathrm{~nm}\left(\mathrm{~A}_{260} / \mathrm{A}_{280}\right)\right]$ for all samples was above 1.9. The RNA integrity was assessed by electrophoretic analysis of $28 \mathrm{~S}$ and $18 \mathrm{~S}$ rRNA subunits using agarose gel electrophoresis.

A portion of the extracted RNA was diluted to 1 $\mu \mathrm{g} / \mu \mathrm{L}$ using DNase-RNase-free water before reverse transcription. The cDNA was synthesized from $1 \mu \mathrm{g}$ of RNA using the iScript cDNA synthesis kit (Bio-Rad Laboratories Inc., Hercules, CA) as per the manufacturer's instructions. A negative control to check for genomic DNA contamination was prepared by pooling RNA from each sample, and using $1 \mu \mathrm{g}$ in a reaction without reverse transcriptase. All first-strand cDNA reactions were diluted 5 fold before use in PCR. Primer sequences used in these experiments along with PCR statistics are detailed in Supplemental Tables 1 and 2 (available online at http://www.journalofdairyscience. org/). The mRNA levels were quantified using the MyiQ single-color real-time PCR detection system (Bio-Rad Laboratories Inc.) and the $2 \times$ iQ SYBR Green PCR Master Mix (Bio-Rad Laboratories Inc.). Cycles were performed as follows: denaturation at $95^{\circ} \mathrm{C}$ for $3 \mathrm{~min}$ to activate the polymerase, followed by 40 cycles of $95^{\circ} \mathrm{C}$ for $15 \mathrm{~s}, 60^{\circ} \mathrm{C}$ for $30 \mathrm{~s}$, and $72^{\circ} \mathrm{C}$ for $30 \mathrm{~s}$. The presence of a single $\mathrm{PCR}$ product and the absence of primer-dimers were verified by the melt curve analysis using incremental temperatures to $95^{\circ} \mathrm{C}$ for $15 \mathrm{~s}$ plus $65^{\circ} \mathrm{C}$ for $15 \mathrm{~s}$. Data were normalized to the housekeeping gene genes ubiquitously expressed, prefoldin-like chaperone $(U X T)$ after comparing the expression of UXT, mitochondrial ribosomal protein L39 (MRPL39), and eukaryotic translation initiation factor 3 , subunit K (EIF3K), as suggested by Kadegowda et al. (2009). The stability of housekeeping genes were tested by NormFinder software (Molecular Diagnostic Laboratory, Aarhus, Denmark). Data were transformed using equation $2^{-\Delta \Delta \mathrm{Ct}}$ (Livak and Schmittgen, 2001), where $\mathrm{Ct}$ represents the fractional cycle number when the amount of amplified product reaches a threshold for fluorescence.
The normalized data were transformed to obtain a perfect mean of 1.0 for the LCFA treatment, leaving the proportional difference between the biological replicates. The same proportional change was calculated in all the treatments to obtain a fold change relative to LCFA treatment.

\section{Protein Isolation and Western Blotting}

Protein isolation and Western blotting procedures were adapted from Rudolph et al. (2010). Briefly, mammary lysis buffer $[50 \mathrm{~m} M$ Tris (pH 7.4), $150 \mathrm{mM} \mathrm{NaCl}$, $2.0 \mathrm{~m} M$ EDTA, $50 \mathrm{~m} M \mathrm{NaF}, 5.0 \mathrm{~m} M$ sodium vanadate, $1 \%$ Triton X-100, $1 \%$ deoxycholate, and $0.1 \%$ SDS] to which $0.57 \mathrm{mM}$ phenylmethylsulfonyl fluoride, $20 \mu \mathrm{L} /$ mL EDTA-free protease inhibitor cocktail (Roche Applied Science, Indianapolis, IN), and $1.0 \mathrm{~m} M$ DTT were added to extract proteins from the mammary samples. Samples were homogenized using a Brinkmann homogenizer (Brinkmann Instruments, Westbury, NY), and lysate was centrifuged at 13,000 $\times g$ for $20 \mathrm{~min}$ at $4^{\circ} \mathrm{C}$. Protein concentrations in the supernatant were determined using bicinchoninic acid (Pierce, Rockford, IL). Proteins were resolved using 8\% SDS polyacrylamide gels (Laemmli, 1970). Resolved proteins were transferred to a nitrocellulose membrane (Bio-Rad Laboratories Inc.). Antibodies directed against ACC 1; (polyclonal antibodies raised in rabbit; catalogue no. 3662S) and FASN (polyclonal antibodies raised in rabbit; catalogue no. 3180S) and secondary antibodies [anti-rabbit IgG, horseradish peroxidase (HRP)-linked antibody; catalogue no. 7074S] were obtained from Cell Signaling Technology Inc. (Danvers, MA; http://www. cellsignal.com). Although the antibodies used were not bovine specific, they had been were validated for use on bovine ACC and FASN by the manufacturer.

\section{Statistical Analysis}

Milk production, milk components, gene expression, protein expression, and FA composition data were analyzed as a $2 \times 2$ factorial arrangement of treatments in $4 \times 4$ Latin square design using PROC MIXED in SAS (version 9.2; SAS Institute Inc., Cary, NC). The statistical model included the random effects of cow and experimental period, and the fixed effects of type of fat (BF or LCFA), CLA (with or without CLA infusion), and fat $\times$ CLA interaction. One cow on the BF-CLA treatment was diagnosed with displaced abomasum and was surgically treated during wk 2 of period 1 . To allow for recovery from surgery, period 1 data from this cow was not included in the analysis. A probability of $P \leq 0.05$ was considered statistically significant. A 
probability of $P \leq 0.10$ was considered as a trend in the results. The results are presented as least squares means.

\section{RESULTS}

The FA profiles of the individual fat supplements are presented in Table 2. The CLA supplement was a mix of $42 \%$ cis- 9 ,trans -11 and $45 \%$ trans- 10 , cis- 12 CLA. The LCFA mixture was formulated to provide an equivalent amount of LCFA of dietary origin, as in the infused BF (Kadegowda et al., 2008), assuming that $50 \%$ of C16 in milk fat is derived from the diet (Palmquist and Jenkins, 1980), such that the difference between BF and LCFA were the presence of the remaining $50 \% \mathrm{C} 16$ and SMCFA.

Intake and milk production responses are presented in Table 3. No significant treatment or interaction effects were observed for DMI and milk yield. However, CLA infusion reduced $3.5 \%$ FCM by $25 \%$ with $\mathrm{BF}$ and LCFA $(P<0.01)$. Feed conversion efficiency $(3.5 \%$ FCM/DMI) was reduced with CLA $(P<0.01)$, whereas no effects were observed with increased availability of SMCFA $(P=0.46)$. Conjugated linoleic acid reduced milk fat percentage by 32 and $41 \%(P<0.01)$ and milk fat yield by 38 and $41 \%(P<0.01)$ with $\mathrm{BF}$ and LCFA, respectively. No treatment effects were observed on milk protein concentration and yield.

Concentrations and yields of individual milk FA in milk fat are presented in Tables 4 and 5, respectively. Abomasal infusion of CLA reduced the secretion of de novo synthesized FA (DNFA), shifting the milk
FA composition toward higher proportions of LCFA $(>16 \mathrm{C})$. Conjugated linoleic acid infusion reduced the proportion of DNFA in milk fat by 11 and $15 \%(P<$ $0.01)$ and yield by 44 and $50 \%(P<0.01)$ with $\mathrm{BF}$ and LCFA, respectively. The concentration and yield of all individual SMCFA including $\mathrm{C} 6, \mathrm{C} 8, \mathrm{C} 10$, and $\mathrm{C} 12$, along with $\mathrm{C} 16$ were reduced $(P<0.01)$ with CLA infusion, with the exception of $\mathrm{C} 14$. The proportion of C14 in milk fat remained constant, whereas the yield was reduced with CLA infusion $(P<0.01)$. The proportions of C18:0, total C18:1, and total C18:2 in milk fat were increased with CLA $(P<0.01)$, whereas the yields of the respective FA were decreased $(P<0.01)$.

The milk FA profile of milk fat was not markedly altered in response to increased availability of SMCFA. Proportions of SMCFA in milk fat, including C6, C8, $\mathrm{C} 10$, and $\mathrm{C} 12$, remained constant, whereas $\mathrm{C} 14: 0$, cis-9 14:1, and cis-9 $16: 1$ increased $(P<0.01)$ with BF infusion. The total DNFA concentration in milk fat tended to be higher with $\mathrm{BF}$ infusion $(P=0.09)$, whereas DNFA yield $(P=0.43)$ remained constant. The content and yield of MUFA and PUFA in milk fat were similar irrespective of type of fat infused. The milk fat content of C18:0 was greater $(P<0.01)$ and total $\mathrm{C} 18: 1$ tended $(P=0.07)$ to be greater with LCFA infusion, whereas the yield of the respective FA remained constant.

Concentrations and yields of individual 18:1 and 18:2 FA isomers in milk fat are shown in Tables 6 and 7, respectively. Total trans $18: 1$, including trans-5/7, trans-8/9, trans-11, trans-13/14, and trans-16, increased with CLA infusion $(P<0.01)$. The proportion of total cis 18:1 $(P=0.09)$, cis-9 $(P=0.10)$ and cis-15 $(P=$

Table 3. Production responses from cows abomasally infused with long-chain FA (LCFA), LCFA with conjugated linoleic acid (LC-CLA), butterfat (BF), or BF with CLA (BF-CLA)

\begin{tabular}{|c|c|c|c|c|c|c|c|c|}
\hline \multirow[b]{2}{*}{ Item } & \multicolumn{4}{|c|}{ Treatment } & \multirow[b]{2}{*}{ SEM } & \multicolumn{3}{|c|}{$P$-value ${ }^{1}$} \\
\hline & LCFA & LC-CLA & $\mathrm{BF}$ & BF-CLA & & Fat & CLA & $\begin{array}{r}\text { Fat } \times \\
\text { CLA }\end{array}$ \\
\hline $\mathrm{n}$ & 4 & 4 & 4 & 3 & & & & \\
\hline $\mathrm{BW}, \mathrm{kg}$ & 713 & 721 & 724 & 713 & 36.1 & 0.83 & 0.83 & 0.16 \\
\hline DMI, kg/d & 25.4 & 22.6 & 24.9 & 24.0 & 1.15 & 0.66 & 0.12 & 0.41 \\
\hline Milk, kg/d & 47.9 & 46.9 & 49.2 & 46.1 & 5.77 & 0.91 & 0.21 & 0.49 \\
\hline Milk $\mathrm{NE}^{2} / \mathrm{NE}$ intake & 0.81 & 0.75 & 0.84 & 0.74 & 0.08 & 0.71 & 0.01 & 0.51 \\
\hline Energy balance, ${ }^{3} \mathrm{Mcal} / \mathrm{d}$ & -2.92 & -1.98 & -5.03 & -2.71 & 3.07 & 0.33 & 0.26 & 0.63 \\
\hline $3.5 \% \mathrm{FCM}, \mathrm{kg} / \mathrm{d}$ & 46.7 & 35.5 & 47.9 & 35.9 & 4.97 & 0.54 & $<0.01$ & 0.13 \\
\hline $3.5 \%$ FCM/DMI & 1.84 & 1.69 & 1.93 & 1.48 & 0.23 & 0.46 & $<0.01$ & 0.09 \\
\hline Milk fat, $\%$ & 3.36 & 1.99 & 3.37 & 2.30 & 0.19 & 0.41 & $<0.01$ & 0.46 \\
\hline Milk fat, $\mathrm{g} / \mathrm{d}$ & 1,600 & 937 & 1,640 & 1,013 & 164 & 0.50 & $<0.01$ & 0.83 \\
\hline Milk protein, \% & 2.93 & 2.97 & 2.98 & 3.05 & 0.06 & 0.33 & 0.40 & 0.87 \\
\hline Milk protein, g/d & 1,410 & 1,394 & 1,471 & 1,388 & 180.0 & 0.59 & 0.36 & 0.53 \\
\hline MUN, mg/dL & 14.3 & 12.0 & 12.5 & 11.9 & 1.31 & 0.40 & 0.21 & 0.46 \\
\hline $\mathrm{SCC}, \times 10^{3} / \mathrm{mL}$ & 110 & 102 & 135 & 162 & 65 & 0.35 & 0.52 & 0.63 \\
\hline
\end{tabular}

${ }^{1}$ Probability that the fat, CLA, or interaction effects were not different from zero.

${ }^{2}$ Milk NE $(\mathrm{Mcal} / \mathrm{kg})=$ milk yield $(\mathrm{kg} / \mathrm{d}) \times[(0.0929 \times$ fat $\%)+(0.0563 \times$ true protein $\%)+0.192](\mathrm{NRC}$, 2001).

${ }^{3}$ Energy balance $(\mathrm{Mcal} / \mathrm{d})=\mathrm{NE}_{\mathrm{L}}$ intake - Milk $\mathrm{NE}-0.08 \times \mathrm{BW}^{0.075}$. 
Table 4. Least squares means for FA composition of milk from cows infused with long-chain FA (LCFA), LCFA with conjugated linoleic acid (LC-CLA), butterfat (BF), or BF with CLA (BF-CLA) ${ }^{1}$

\begin{tabular}{|c|c|c|c|c|c|c|c|c|}
\hline \multirow[b]{2}{*}{$\begin{array}{l}\text { FA, } \\
\mathrm{g} / 100 \mathrm{~g} \text { of } \mathrm{FAME}^{2}\end{array}$} & \multicolumn{4}{|c|}{ Treatment } & \multirow[b]{2}{*}{ SEM } & \multicolumn{3}{|c|}{$P$-value ${ }^{3}$} \\
\hline & LCFA & LC- CLA & $\mathrm{BF}$ & BF- CLA & & Fat & CLA & $\begin{array}{r}\text { Fat } \times \\
\text { CLA }\end{array}$ \\
\hline 4:0 & 3.59 & 3.44 & 3.28 & 3.15 & 0.58 & 0.52 & 0.12 & 0.98 \\
\hline $6: 0$ & 2.12 & 1.47 & 1.91 & 1.43 & 0.19 & 0.35 & $<0.01$ & 0.52 \\
\hline 8:0 & 1.29 & 0.91 & 1.18 & 0.87 & 0.10 & 0.33 & $<0.01$ & 0.66 \\
\hline 10:0 & 2.96 & 2.08 & 2.86 & 1.96 & 0.25 & 0.42 & $<0.01$ & 0.95 \\
\hline $12: 0$ & 3.52 & 2.72 & 3.73 & 2.78 & 0.28 & 0.35 & 0.01 & 0.60 \\
\hline 13:0 & 0.22 & 0.15 & 0.28 & 0.17 & 0.03 & 0.08 & $<0.01$ & 0.40 \\
\hline $14: 0$ & 11.09 & 10.78 & 12.19 & 11.51 & 0.38 & $<0.01$ & 0.09 & 0.41 \\
\hline cis-9 14:1 & 1.01 & 1.09 & 1.33 & 1.25 & 0.15 & 0.01 & 0.98 & 0.25 \\
\hline $15: 0$ & 1.06 & 0.91 & 1.39 & 1.01 & 0.17 & 0.11 & 0.06 & 0.38 \\
\hline 16:0 & 30.33 & 27.62 & 31.18 & 28.97 & 0.75 & 0.13 & 0.01 & 0.70 \\
\hline cis-9 16:1 & 1.51 & 1.56 & 1.82 & 1.76 & 0.19 & $<0.01$ & 0.96 & 0.41 \\
\hline cis-11 16:1 & 0.04 & 0.07 & 0.06 & 0.09 & 0.01 & 0.01 & $<0.01$ & 0.54 \\
\hline $17: 0$ & 0.47 & 0.48 & 0.52 & 0.48 & 0.04 & 0.09 & 0.36 & 0.18 \\
\hline 18:0 & 7.76 & 9.23 & 6.75 & 8.68 & 0.71 & $<0.01$ & $<0.01$ & 0.18 \\
\hline $18: 1$ & 24.38 & 27.02 & 22.39 & 25.28 & 1.51 & 0.07 & 0.02 & 0.89 \\
\hline $18: 2$ & 3.85 & 5.26 & 3.76 & 4.78 & 0.41 & 0.47 & 0.02 & 0.62 \\
\hline cis-9,cis-12,cis-15 18:3 & 0.24 & 0.26 & 0.25 & 0.26 & 0.02 & 0.89 & 0.52 & 0.79 \\
\hline $20: 0$ & 0.14 & 0.15 & 0.12 & 0.15 & 0.00 & 0.10 & 0.01 & 0.34 \\
\hline cis-9 20:1 & 0.09 & 0.09 & 0.09 & 0.09 & 0.00 & 0.69 & 0.22 & 0.83 \\
\hline $22: 0$ & 0.02 & 0.02 & 0.01 & 0.02 & 0.00 & 0.05 & 0.49 & 0.20 \\
\hline $22: 4$ & 0.04 & 0.03 & 0.04 & 0.03 & 0.00 & 0.89 & 0.04 & 0.66 \\
\hline $22: 5$ & 0.05 & 0.04 & 0.05 & 0.04 & 0.00 & 0.91 & $<0.01$ & 0.55 \\
\hline Other & 4.18 & 4.56 & 4.82 & 4.79 & 0.17 & 0.02 & 0.22 & 0.17 \\
\hline $\mathrm{DNFA}^{4}$ & 42.57 & 36.06 & 43.27 & 38.64 & 1.52 & 0.09 & $<0.01$ & 0.28 \\
\hline MUFA & 27.69 & 30.63 & 26.51 & 29.39 & 1.59 & 0.19 & 0.01 & 0.97 \\
\hline PUFA & 4.34 & 5.78 & 4.26 & 5.33 & 0.44 & 0.54 & 0.02 & 0.65 \\
\hline SFA & 66.27 & 61.62 & 67.18 & 63.29 & 2.15 & 0.32 & 0.01 & 0.76 \\
\hline
\end{tabular}

${ }^{1} \mathrm{n}=3$ for BF-CLA and 4 per treatment for the other treatments.

${ }^{2} \mathrm{FAME}=\mathrm{FA}$ methyl esters.

${ }^{3}$ Probability that the fat, CLA, or interaction effects were not different from zero.

${ }^{4}$ De novo synthesized FA (includes C4 to $\mathrm{C} 14$ and $50 \%$ of $\mathrm{C} 16 \mathrm{FA}$ ).

$0.10)$ in milk fat tended to increase, whereas cis-13 $(P$ $<0.01)$ and cis-14 18:1 $(P=0.04)$ were increased with CLA infusion. Abomasal infusion of CLA increased total CLA concentration in milk fat by 166 and $116 \%$ and CLA yields by 56 and $43 \%(P<0.01)$ with LCFA and $\mathrm{BF}$, respectively. Proportions of concentrations of individual CLA isomers in milk fat, including cis9,trans-11, trans-10,cis-12, trans-9,cis-11, and trans11,trans-13 $(P<0.01)$ were also increased. Similarly, CLA infusion tended to increase cis-9,trans-11 CLA yield $(P=0.06)$ by 29 and $27 \%$ with LCFA and BF treatments, respectively, with a transfer efficiency of approximately $17 \%$ and increased the yield $(P<0.01)$ of trans-10,cis-12 with a transfer efficiency of 19 and $20 \%$ with LCFA and BF, respectively.

Mammary lipogenic gene expression in response to various treatments is presented in Table 8. Abomasal infusion of CLA markedly altered expression of most lipogenic genes. The mRNA abundance of $A C C, F A S N$, AGPAT-6, DGAT-1, LPL, and SREBP-1 were reduced $(P<0.01)$ with CLA infusion. However, $S C D-1$ and $P P A R-\gamma$ were unaffected by CLA. Increased availabil- ity of SMCFA with BF significantly increased mRNA abundance of $L P L(P=0.03)$ and tended to increase $(P$ $=0.08)$ AGPAT abundance. The interaction between type of fat and CLA was significant for $S C D-1(P<$ $0.05)$. The mRNA expression of insulin-induced gene 1 (INSIG-1) was reduced with CLA. Protein expression for the lipogenic enzymes ACC and FASN, (Figures 2 and 3 , respectively) was significantly reduced $(P<$ 0.01) in response to CLA, whereas no effects were observed with increased SMCFA availability.

\section{DISCUSSION}

During MFD, the SMCFA are reduced to a greater extent relative to LCFA in milk fat. Our hypothesis was that postruminal infusion of SMCFA could alleviate at least a portion of CLA-induced MFD. Butterfat, used as a source of SMCFA, provided an additional 190 $\mathrm{g}$ of SMCFA/d compared with the LCFA treatment, such that the production responses observed by comparing $\mathrm{BF}$ and LCFA treatments could be attributed to differences in SMCFA availability for absorption in 
Table 5. Least squares means for FA yield (g/d) of milk from cows abomasally infused with long-chain FA (LCFA), LCFA with conjugated linoleic acid (LC-CLA), butterfat (BF), or BF with CLA (BF-CLA) ${ }^{1}$

\begin{tabular}{|c|c|c|c|c|c|c|c|c|}
\hline \multirow[b]{2}{*}{$\begin{array}{l}\text { FA, } \\
\mathrm{g} \text { of } \mathrm{FAME}^{2} / \mathrm{d}\end{array}$} & \multicolumn{4}{|c|}{ Treatment } & \multirow[b]{2}{*}{ SEM } & \multicolumn{3}{|c|}{$P$-value ${ }^{3}$} \\
\hline & LCFA & LC-CLA & $\mathrm{BF}$ & BF-CLA & & Fat & CLA & $\begin{array}{l}\text { Fat } \times \\
\text { CLA }\end{array}$ \\
\hline 4:0 & 56.5 & 33.9 & 52.3 & 37.0 & 8.84 & 0.94 & 0.03 & 0.60 \\
\hline $6: 0$ & 33.7 & 14.5 & 31.4 & 14.8 & 3.95 & 0.71 & $<0.01$ & 0.63 \\
\hline 8:0 & 20.7 & 8.8 & 19.6 & 8.9 & 2.72 & 0.77 & $<0.01$ & 0.75 \\
\hline 10:0 & 48.2 & 20.3 & 47.6 & 20.1 & 7.14 & 0.93 & $<0.01$ & 0.96 \\
\hline $12: 0$ & 57.6 & 26.3 & 62.2 & 28.0 & 8.99 & 0.56 & $<0.01$ & 0.79 \\
\hline 13:0 & 3.5 & 1.4 & 4.7 & 1.5 & 0.73 & 0.29 & $<0.01$ & 0.33 \\
\hline $14: 0$ & 178.8 & 102.9 & 200.7 & 116.0 & 21.44 & 0.13 & $<0.01$ & 0.67 \\
\hline cis-9 14:1 & 15.8 & 10.0 & 21.5 & 12.7 & 2.22 & $<0.01$ & $<0.01$ & 0.17 \\
\hline $15: 0$ & 17.6 & 8.7 & 23.5 & 9.1 & 3.99 & 0.30 & $<0.01$ & 0.35 \\
\hline $16: 0$ & 489.4 & 261.0 & 512.1 & 291.0 & 57.00 & 0.39 & $<0.01$ & 0.90 \\
\hline cis-9 16:1 & 24.2 & 14.6 & 30.0 & 17.6 & 3.94 & $<0.01$ & $<0.01$ & 0.21 \\
\hline cis-11 16:1 & 0.6 & 0.7 & 1.0 & 0.9 & 0.14 & $<0.01$ & 0.40 & 0.13 \\
\hline $17: 0$ & 7.6 & 4.5 & 8.8 & 4.8 & 1.19 & 0.29 & $<0.01$ & 0.49 \\
\hline 18:0 & 123.3 & 85.9 & 110.8 & 94.83 & 15.41 & 0.87 & 0.06 & 0.36 \\
\hline $18: 1$ & 384.5 & 246.9 & 365.8 & 255.7 & 32.39 & 0.75 & $<0.01$ & 0.39 \\
\hline $18: 2$ & 61.0 & 48.0 & 61.4 & 49.2 & 5.99 & 0.81 & $<0.01$ & 0.89 \\
\hline cis-9,cis-12,cis-15 18:3 & 3.8 & 2.4 & 4.1 & 2.7 & 0.31 & 0.14 & $<0.01$ & 0.98 \\
\hline $20: 0$ & 2.2 & 1.4 & 1.2 & 1.5 & 0.25 & 0.81 & 0.02 & 0.38 \\
\hline cis-9 20:1 & 1.3 & 0.8 & 1.4 & 0.9 & 0.14 & 0.33 & $<0.01$ & 0.76 \\
\hline $22: 0$ & 0.4 & 0.2 & 0.3 & 0.2 & 0.06 & 0.60 & 0.03 & 0.70 \\
\hline $22: 4$ & 0.7 & 0.3 & 0.7 & 0.3 & 0.12 & 0.75 & $<0.01$ & 0.61 \\
\hline $22: 5$ & 0.9 & 0.4 & 0.9 & 0.4 & 0.13 & 0.74 & $<0.01$ & 0.86 \\
\hline $\mathrm{DNFA}^{4}$ & 685.7 & 343.8 & 710.3 & 395.9 & 82.54 & 0.43 & $<0.01$ & 0.77 \\
\hline MUFA & 437.1 & 280.3 & 433.1 & 295.7 & 37.85 & 0.72 & $<0.01$ & 0.54 \\
\hline PUFA & 68.5 & 52.9 & 69.8 & 54.7 & 6.75 & 0.67 & $<0.01$ & 0.94 \\
\hline SFA & $1,066.9$ & 585.4 & $1,105.0$ & 646.5 & 127.60 & 0.51 & $<0.01$ & 0.88 \\
\hline
\end{tabular}

${ }^{1} \mathrm{n}=3$ for BF-CLA and 4 per treatment for the other treatments.

${ }^{2} \mathrm{FAME}=\mathrm{FA}$ methyl esters.

${ }^{3}$ Probability that the fat, CLA, or interaction effects were not different from zero.

${ }^{4}$ De novo synthesized fatty acids (includes C4-C14 and 50\% of C16 FA).

the small intestine. The CLA supplement used in the present study for inducing MFD contained 2 major CLA isomers: trans-10,cis-12 CLA and cis-9,trans-11 CLA. Because previous studies have shown that the cis-9,trans-11 CLA isomer had no effect on milk fat synthesis in lactating dairy cows (Baumgard et al., 2000; Baumgard et al., 2002; Loor and Herbein, 2003), the milk fat responses with CLA supplement in the present study can be attributed to the trans-10, cis-12 CLA isomer.

The abomasal infusion of the CLA mixture in the present study tended to reduce DMI, whereas no effects were observed on total milk yield. Previous studies reported depressed DMI with abomasal infusion of unsaturated LCFA (Drackley et al., 1992; Christensen et al., 1994; Bremmer et al., 1998) and attributed it to the presence of higher C18:2 content in the infused fat supplements (Bremmer et al., 1998). It was suggested that free FA, upon once reaching the duodenum, might stimulate the release of cholecystokinin that may suppress intake (Woltman et al., 1995), further explaining the CLA-induced tendency to reduce intake in the present study. However, the lack of significant effects might be due to lesser quantities of unsaturated FA infused compared with previous studies. Our assumption is further supported by results observed using similar amounts of either intravenous $(10 \mathrm{~g} / \mathrm{d}$; Gervais et al., 2009) or abomasal infusion of trans-10,cis-12 CLA (10 g/d; Kadegowda et al., 2008). On the contrary, both milk fat percentage and yield were significantly reduced by CLA infusion, further verifying the role of trans10, cis-12 CLA as a potent inhibitor of milk fat synthesis (Chouinard et al., 1999; Baumgard et al., 2000).

Milk FA profile during MFD is characterized by reduced secretion of FA originating from de novo synthesis and reduced FA uptake from the circulation, with effects more pronounced on DNFA (Bauman and Griinari, 2003). Similar shifts in the FA profile were observed in the present study. The CLA-induced shifts in the milk FA profile suggest reduced mammary lipogenesis (Piperova et al., 2000). Consistent with this observation, the mRNA abundance of genes involved in de novo FA synthesis ( $A C A C A$ and $F A S N$ ), uptake of circulating FA $(L P L)$, and triglyceride synthesis 
Table 6. Least squares means for FA composition of C18:1 and C18:2 isomers in milk fat from cows abomasally infused with long-chain FA (LCFA), LCFA with conjugated linoleic acid (LC-CLA), butterfat (BF), or BF with CLA (BF-CLA) ${ }^{1}$

\begin{tabular}{|c|c|c|c|c|c|c|c|c|}
\hline \multirow[b]{2}{*}{$\begin{array}{l}\text { FA, } \\
\mathrm{g} / 100 \mathrm{~g} \text { of } \mathrm{FAME}^{2}\end{array}$} & \multicolumn{4}{|c|}{ Treatment } & \multirow[b]{2}{*}{ SEM } & \multicolumn{3}{|c|}{$P$-value ${ }^{3}$} \\
\hline & LCFA & LC-CLA & $\mathrm{BF}$ & BF-CLA & & Fat & CLA & $\begin{array}{l}\text { Fat } \times \\
\text { CLA }\end{array}$ \\
\hline \multicolumn{9}{|l|}{$18: 1$} \\
\hline trans $-5 / 7$ & 0.13 & 0.20 & 0.13 & 0.22 & 0.02 & 0.22 & $<0.01$ & 0.15 \\
\hline trans-8/9 & 0.28 & 0.37 & 0.36 & 0.40 & 0.04 & 0.03 & 0.02 & 0.20 \\
\hline trans-10 & 0.37 & 1.01 & 0.83 & 1.08 & 0.43 & 0.37 & 0.17 & 0.49 \\
\hline trans-11 & 0.75 & 0.92 & 0.65 & 0.91 & 0.11 & 0.54 & 0.04 & 0.61 \\
\hline trans-12 & 0.35 & 0.30 & 0.34 & 0.36 & 0.07 & 0.66 & 0.76 & 0.57 \\
\hline trans-13/14 & 0.40 & 0.56 & 0.55 & 0.65 & 0.05 & $<0.01$ & $<0.01$ & 0.11 \\
\hline trans-16 & 0.19 & 0.22 & 0.21 & 0.26 & 0.01 & $<0.01$ & $<0.01$ & 0.32 \\
\hline Total trans & 2.44 & 3.57 & 3.08 & 3.82 & 0.53 & 0.16 & 0.01 & 0.49 \\
\hline cis-9 & 20.94 & 22.35 & 18.23 & 20.35 & 1.79 & 0.05 & 0.10 & 0.70 \\
\hline cis-11 & 0.63 & 0.71 & 0.63 & 0.69 & 0.07 & 0.80 & 0.15 & 0.70 \\
\hline cis-12 & 0.22 & 0.21 & 0.25 & 0.27 & 0.03 & 0.11 & 0.82 & 0.62 \\
\hline cis-13 & 0.04 & 0.05 & 0.05 & 0.07 & 0.01 & 0.02 & 0.01 & 0.59 \\
\hline cis-14 & 0.04 & 0.03 & 0.05 & 0.04 & 0.00 & $<0.01$ & 0.04 & 0.50 \\
\hline cis-15 & 0.05 & 0.07 & 0.07 & 0.08 & 0.01 & 0.06 & 0.10 & 0.30 \\
\hline cis-16 & 0.01 & 0.01 & 0.01 & 0.02 & 0.00 & 0.11 & 0.39 & 0.43 \\
\hline Total cis & 21.92 & 23.44 & 19.30 & 21.49 & 1.79 & 0.05 & 0.09 & 0.72 \\
\hline \multicolumn{9}{|l|}{$18: 2$} \\
\hline trans-11,trans-15 & 0.02 & 0.02 & 0.02 & 0.02 & 0.00 & 0.04 & 0.69 & 0.87 \\
\hline trans-9,trans-12 & 0.09 & 0.07 & 0.10 & 0.09 & 0.01 & $<0.01$ & 0.03 & 0.49 \\
\hline cis-9,trans-13 & 0.09 & 0.10 & 0.15 & 0.13 & 0.01 & $<0.01$ & 0.22 & 0.04 \\
\hline trans-11,cis-15 & 0.04 & 0.05 & 0.05 & 0.05 & 0.00 & 0.99 & 0.44 & 0.75 \\
\hline cis-9,cis-12 & 3.10 & 3.66 & 2.85 & 3.23 & 0.30 & 0.26 & 0.14 & 0.74 \\
\hline cis-9,cis-15 & 0.02 & 0.04 & 0.03 & 0.03 & 0.00 & 0.86 & 0.37 & 0.18 \\
\hline \multicolumn{9}{|l|}{ CLA } \\
\hline cis-9,trans-11 & 0.39 & 0.87 & 0.44 & 0.83 & 0.09 & 0.99 & $<0.01$ & 0.60 \\
\hline trans -10, cis -12 & 0.01 & 0.27 & 0.01 & 0.25 & 0.04 & 0.77 & $<0.01$ & 0.71 \\
\hline trans-7,cis-9 & 0.04 & 0.04 & 0.05 & 0.04 & 0.00 & 0.08 & 0.60 & 0.22 \\
\hline trans- 8, cis- 10 & 0.03 & 0.04 & 0.03 & 0.01 & 0.00 & 0.13 & 0.99 & 0.16 \\
\hline trans-9,cis-11 & 0.01 & 0.03 & 0.01 & 0.02 & 0.00 & 0.83 & $<0.01$ & 0.06 \\
\hline trans -11, trans -13 & 0.01 & 0.03 & 0.01 & 0.02 & 0.00 & 0.26 & 0.01 & 0.25 \\
\hline Total CLA & 0.50 & 1.33 & 0.56 & 1.21 & 0.12 & 0.81 & $<0.01$ & 0.47 \\
\hline
\end{tabular}

${ }^{1} \mathrm{n}=3$ for BF-CLA and 4 per treatment for the other treatments.

${ }^{2}$ FAME $=$ FA methyl esters.

${ }^{3}$ Probability that the fat, CLA, or interaction effects were not different from zero.

(DGAT-1 and AGPAT-6) were significantly reduced. The results are consistent with the previous studies using pure trans-10,cis-12 CLA isomer (Baumgard et al., 2002; Gervais et al., 2009) or during diet-induced MFD (Opstvedt et al., 1967; Piperova et al., 2000; Peterson et al., 2003). However, transcriptional regulation may be insufficient to completely describe protein abundance because of extensive posttranscriptional regulation that might lead to low correlation between mRNA and protein concentrations (Vogel et al., 2010). Previous studies did not investigate the lipogenic protein expression in response to trans-10, cis-12 CLA infusions and assumed a similar level of reduction based on reduced milk fat synthesis. The findings from the present study showing reduced protein expression of ACC and FASN provides evidence that mRNA expression correlates well with lipogenic protein expression during trans-10, cis-12 CLA-induced MFD.
The coordinated downregulation of mammary lipogenic gene expression with trans-10,cis-12 CLA suggests the involvement of transcriptional regulation of mammary lipogenesis (Peterson et al., 2004; Harvatine and Bauman, 2006). The SREBP-1 gene has been suggested as a global regulator of mammary lipid metabolism (Rudolph et al., 2007) both in vitro in mammary epithelial cells (Peterson et al., 2004) and in lactating dairy cows (Harvatine and Bauman, 2006). Mammary mRNA abundance of $S R E P B-1$ was reduced in response to trans-10,cis-12 CLA in the present study, with no effects observed on $S C A P$, and the results are in line with other studies in dairy cows (Harvatine and Bauman, 2006; Gervais et al., 2009). However, as observed in previous studies (Harvatine and Bauman, 2006; Kadegowda et al., 2009), the expression of INSIG-1 was reduced in response to trans-10,cis-12 CLA. Bionaz and Loor (2008) showed a positive correlation between INSIG-1 
Table 7. Least squares means for FA yield of C18:1 and C18:2 isomers in milk fat from cows abomasally infused with long-chain FA (LCFA), LCFA with conjugated linoleic acid (LC-CLA), butterfat (BF), or BF with CLA (BF-CLA) ${ }^{1}$

\begin{tabular}{|c|c|c|c|c|c|c|c|c|}
\hline \multirow[b]{2}{*}{$\begin{array}{l}\mathrm{FA}, \\
\mathrm{g} \text { of } \mathrm{FAME}^{2} / \mathrm{d}\end{array}$} & \multicolumn{4}{|c|}{ Treatment } & \multirow[b]{2}{*}{ SEM } & \multicolumn{3}{|c|}{$P$-value ${ }^{3}$} \\
\hline & LCFA & LC-CLA & $\mathrm{BF}$ & BF-CLA & & Fat & CLA & $\begin{array}{c}\text { Fat } \times \\
\text { CLA }\end{array}$ \\
\hline \multicolumn{9}{|l|}{$18: 1$} \\
\hline trans $-5 / 7$ & 2.08 & 1.90 & 2.12 & 2.38 & 0.33 & 0.07 & 0.72 & 0.11 \\
\hline trans-8/9 & 4.50 & 3.59 & 5.99 & 4.16 & 0.87 & 0.02 & $<0.01$ & 0.22 \\
\hline trans-10 & 5.67 & 10.69 & 14.14 & 13.25 & 5.83 & 0.13 & 0.53 & 0.38 \\
\hline trans-11 & 11.64 & 8.81 & 10.69 & 10.05 & 1.63 & 0.88 & 0.13 & 0.30 \\
\hline trans-12 & 5.61 & 2.93 & 5.61 & 3.81 & 1.17 & 0.64 & 0.06 & 0.65 \\
\hline trans-13/14 & 6.48 & 5.42 & 9.13 & 6.88 & 1.38 & 0.01 & 0.03 & 0.34 \\
\hline trans- 16 & 3.01 & 2.08 & 3.49 & 2.68 & 0.41 & 0.07 & 0.01 & 0.81 \\
\hline Total trans & 39.00 & 35.43 & 51.18 & 41.51 & 9.83 & 0.10 & 0.21 & 0.54 \\
\hline cis-9 & 329.54 & 201.04 & 296.56 & 202.85 & 24.14 & 0.23 & $<0.01$ & 0.19 \\
\hline cis-11 & 10.10 & 6.70 & 10.65 & 6.53 & 1.58 & 0.79 & $<0.01$ & 0.61 \\
\hline cis-12 & 3.52 & 1.99 & 4.12 & 2.69 & 0.43 & 0.04 & $<0.01$ & 0.86 \\
\hline cis-13 & 0.59 & 0.51 & 0.86 & 0.75 & 0.16 & 0.01 & 0.23 & 0.80 \\
\hline cis-14 & 0.58 & 0.32 & 0.75 & 0.40 & 0.11 & $<0.01$ & $<0.01$ & 0.14 \\
\hline cis-15 & 0.76 & 0.69 & 1.18 & 0.85 & 0.24 & 0.03 & 0.11 & 0.25 \\
\hline cis-16 & 0.18 & 0.11 & 0.24 & 0.18 & 0.05 & 0.20 & 0.18 & 0.86 \\
\hline Total cis & 345.26 & 211.37 & 314.36 & 213.99 & 26.03 & 0.28 & $<0.01$ & 0.21 \\
\hline \multicolumn{9}{|l|}{$18: 2$} \\
\hline trans-11,trans-15 & 0.31 & 0.18 & 0.39 & 0.23 & 0.06 & 0.08 & $<0.01$ & 0.63 \\
\hline trans -9, trans -12 & 1.40 & 0.69 & 1.74 & 0.97 & 0.25 & 0.07 & $<0.01$ & 0.84 \\
\hline cis-9,trans-13 & 1.52 & 0.99 & 2.5 & 1.33 & 0.32 & $<0.01$ & $<0.01$ & $<0.01$ \\
\hline trans-11,cis-15 & 0.69 & 0.48 & 0.75 & 0.52 & 0.09 & 0.44 & 0.02 & 0.89 \\
\hline cis -9, cis- 12 & 49.02 & 33.32 & 46.47 & 33.19 & 4.36 & 0.55 & $<0.01$ & 0.59 \\
\hline cis-9,cis-15 & 0.37 & 0.34 & 0.46 & 0.30 & 0.08 & 0.66 & 0.08 & 0.18 \\
\hline \multicolumn{9}{|l|}{ CLA } \\
\hline cis-9,trans-11 & 6.12 & 7.94 & 7.13 & 9.04 & 0.94 & 0.22 & 0.06 & 0.95 \\
\hline trans-10, cis-12 & 0.11 & 2.41 & 0.17 & 2.61 & 0.30 & 0.61 & $<0.01$ & 0.77 \\
\hline trans-7,cis-9 & 0.60 & 0.41 & 0.86 & 0.47 & 0.13 & 0.03 & $<0.01$ & 0.09 \\
\hline trans -8, cis -10 & 0.46 & 0.36 & 0.45 & 0.19 & 0.11 & 0.32 & 0.09 & 0.38 \\
\hline trans -9, cis -11 & 0.16 & 0.26 & 0.24 & 0.25 & 0.06 & 0.24 & 0.11 & 0.15 \\
\hline trans-11,trans-13 & 0.19 & 0.25 & 0.26 & 0.22 & 0.04 & 0.54 & 0.69 & 0.16 \\
\hline Total CLA & 7.74 & 12.06 & 9.07 & 12.95 & 1.25 & 0.32 & $<0.01$ & 0.83 \\
\hline
\end{tabular}

expression and the ratio of synthesized/imported FA in the mammary gland and suggested the involvement of INSIG-1 in inducing FA synthesis. The assumption is supported by data from our study with decreased INSIG-1 expression, with trans-10,cis-12 CLA-induced reduction in milk fat.

The SREBP-1 transcription factor cannot bind LCFA directly (Pégorier et al., 2004); thus, the effects of trans-10,cis-12 CLA on the expression/activity of $S R E B P-1$ are probably indirect and might be dependent on other upstream transcription regulators with the ability to bind LCFA (Kadegowda et al., 2009). The LCFA including unsaturated FA are potent agonists of PPAR- $\gamma$ (Xu et al., 1999). Bionaz and Loor (2008) suggested that $P P A R-\gamma$ could be the main transcription factor controlling milk fat synthesis by serving as a regulator for $S R E B P$ activity. Kadegowda et al. (2009) also showed marked upregulation of mammary lipogenic gene expression with rosiglitazone, a $P P A R-\gamma$ agonist, in bovine mammary epithelial cells. However, mRNA expression of PPAR- $\gamma$ in cows was not altered in the present study, nor in cows fed MFD diets for 21 d (Invernizzi et al., 2010), or after 14 d of a MFD diet in the study of Harvatine and Bauman (2006). Thus, the overall role of $P P A R-\gamma$ in the MFD syndrome, if any, is unclear.

Stearoyl CoA desaturase plays an important role in regulating the synthesis of milk fat TG and maintaining milk fat fluidity by endogenous synthesis of cis-9 C18:1 from C18:0 (Bickerstaffe and Johnson, 1972; Loor and Herbein, 2003). The trans-10,cis-12 CLA-induced effects on $S C D-1$ gene expression are inconsistent. The lack of differences in $S C D$-1 gene expression observed in the present study agrees with findings from previous studies (Harvatine and Bauman, 2006; Kadegowda, 2008). Baumgard et al. (2002) showed reduced $S C D$-1 
$\mathrm{ACC}-\alpha$

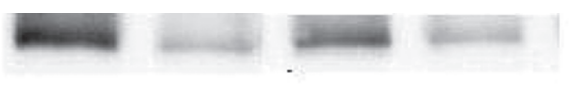

$\beta$-Tubulin

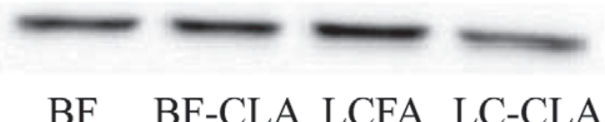

BF BF-CLA LCFA LC-CLA

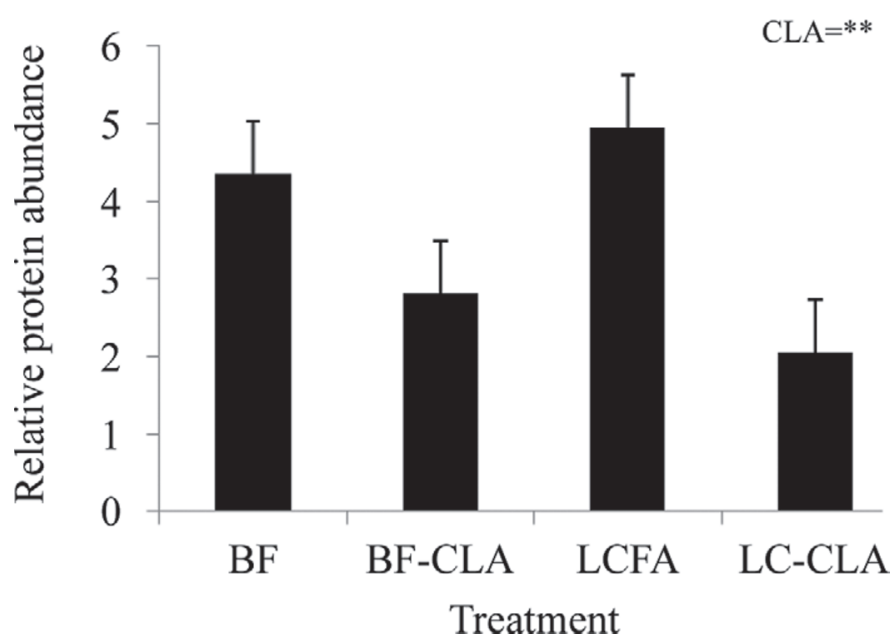

Figure 2. Immunoblots for acetyl-CoA carboxylase (ACC- $\alpha$ ) protein expression in mammary tissue in response to abomasal infusion of different fat supplements. Bars represent the LSM \pm SEM of the ACC- $\alpha$ (normalized to $\beta$-tubulin); $\mathrm{n}=3$ for butterfat with conjugated linoleic acid (BF-CLA) and 4 per treatment for the other treatments; ${ }^{* *} P<0.01 ; \mathrm{LCFA}=$ long-chain $\mathrm{FA} ; \mathrm{LC}-\mathrm{CLA}=\mathrm{LCFA}$ with CLA.

gene expression in response to trans-10, cis-12 CLA infusion. The discrepancy between these results might be attributed to dose (10 vs. $13.6 \mathrm{~g} / \mathrm{d}$ ) or, more likely, the duration (14 vs. 5 d) of trans-10,cis-12 CLA infusion.
FASN
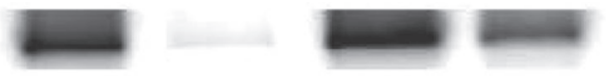

\section{$\beta$-Tubulin}
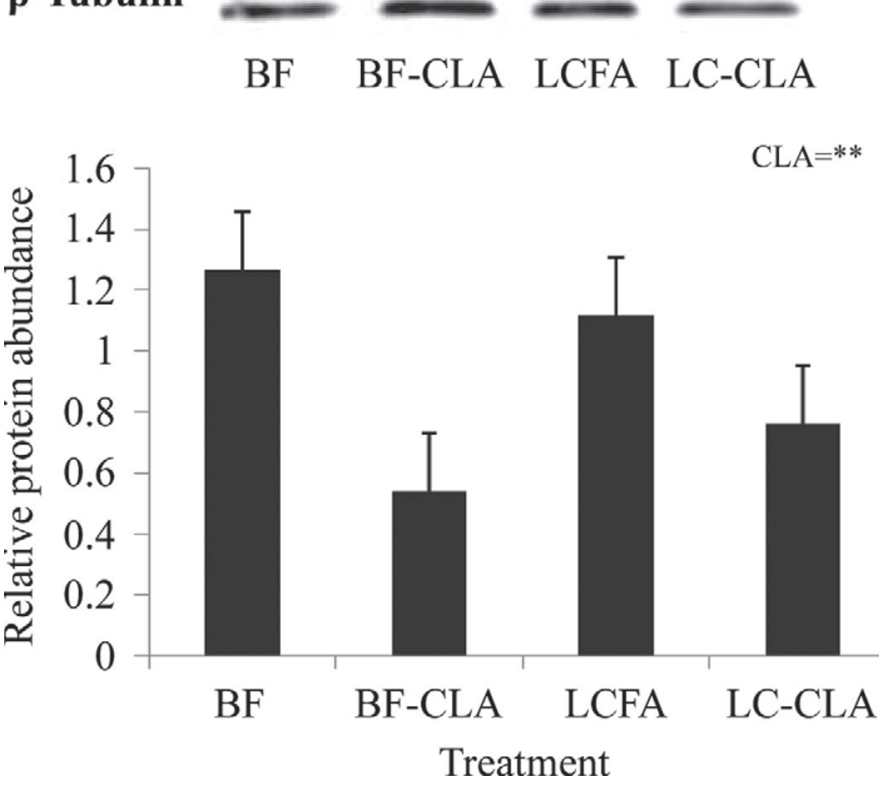

Figure 3. Immunoblots for FA synthase (FASN) protein expression in mammary tissue in response to abomasal infusion of different fat supplements. Bars represent the LSM \pm SEM of the FASN (normalized to $\beta$-tubulin); $\mathrm{n}=3$ for butterfat with conjugated linoleic acid (BF-CLA) and 4 per treatment for the other treatments; ${ }^{* *} P<0.01$; LCFA = long-chain FA; LC-CLA = LCFA with CLA.

Invernizzi et al. (2010) found that $S C D-1$ gene expression increased in response to lipid feeding or MFD in dairy cows at 7-d postfeeding. However, no differences in expression were detected at $21 \mathrm{~d}$ across all treatments,

Table 8. Relative mRNA abundance of mammary lipogenic gene expression from cows abomasally infused with long-chain FA (LCFA), LCFA with conjugated linoleic acid (LC-CLA), butterfat (BF), or BF with CLA $(\mathrm{BF}-\mathrm{CLA})^{1}$

\begin{tabular}{|c|c|c|c|c|c|c|c|c|}
\hline \multirow[b]{2}{*}{ Gene $^{2}$} & \multicolumn{4}{|c|}{ Treatment } & \multirow[b]{2}{*}{ SEM } & \multicolumn{3}{|c|}{$P$-value ${ }^{3}$} \\
\hline & LCFA & LC-CLA & $\mathrm{BF}$ & BF-CLA & & Fat & CLA & $\begin{array}{r}\text { Fat } \times \\
\text { CLA }\end{array}$ \\
\hline$A C A C A$ & 1.0 & 0.53 & 1.37 & 0.75 & 0.68 & 0.21 & 0.03 & 0.76 \\
\hline$F A S N$ & 1.0 & 0.43 & 1.12 & 0.68 & 0.20 & 0.19 & $<0.01$ & 0.67 \\
\hline$L P L$ & 1.0 & 0.54 & 1.69 & 0.83 & 0.33 & 0.03 & $<0.01$ & 0.09 \\
\hline$S C D-1$ & 1.0 & 1.30 & 1.45 & 0.80 & 0.28 & 0.89 & 0.33 & 0.03 \\
\hline AGPAT- 6 & 1.0 & 0.66 & 1.91 & 0.59 & 0.36 & 0.08 & $<0.01$ & 0.06 \\
\hline$D G A T-1$ & 1.0 & 0.67 & 1.23 & 0.70 & 0.22 & 0.30 & $<0.01$ & 0.47 \\
\hline SREBP-1 & 1.0 & 0.36 & 1.01 & 0.41 & 0.77 & 0.77 & $<0.001$ & 0.88 \\
\hline$P P A R-\gamma$ & 1.0 & 1.56 & 1.29 & 1.02 & 0.24 & 0.60 & 0.64 & 0.11 \\
\hline$I N S I G-1$ & 1.0 & 0.16 & 0.67 & 0.41 & 0.23 & 0.82 & $<0.01$ & 0.21 \\
\hline$S C A P$ & 1.0 & 0.50 & 1.03 & 0.95 & 0.14 & 0.60 & 0.64 & 0.11 \\
\hline
\end{tabular}

${ }^{1} \mathrm{n}=3$ for BF-CLA and 4 per treatment for the other treatments.

${ }^{2} A C A C A=$ acetyl-CoA carboxylase $\alpha ; F A S N=$ FA synthase $L P L=$ lipoprotein lipase $S C D-1=$ stearoyl-CoA desaturase 1; AGPAT-6 = 1-acylglycerol-3-phosphate O-acyltransferase $6 ; D G A T-1=$ diacylglycerol O-acyltransferase $1 ; S R E B P-1=$ sterol regulatory element-binding protein $1 ; P P A R-\gamma=$ peroxisome proliferator-activated receptor $\gamma$; INSIG-1 = insulin-induced gene 1; SCAP = SREBP cleavage-activating protein.

${ }^{3}$ Probability that the fat, CLA, or interaction effects were not different from zero. 
suggesting long-term adaptations in gene expression to the influx of different FA (Invernizzi et al., 2010). Thus, the single end-point measurement of gene expression at $14 \mathrm{~d}$ postinfusion might reflect long-term adaptation by the mammary gland, resulting in a lack of differences in gene expression across treatments.

Contrary to the responses observed with CLA, the increased availability of SMCFA had no effect on milk fat synthesis. Previous studies have reported variable milk fat responses to individual SMCFA supplemented either as TG or free FA. Intravenous infusion of TG containing SCFA (C3, C4, C6, C8, C9, and C10) showed no effect, whereas infusion of medium-chain TG increased milk fat yield (Storry et al., 1969). Medium-chain FA either reduced (Hristov et al., 2011) or showed no effect (Hristov et al., 2009) on milk fat yield. Coconut oil, used as a source of $\mathrm{C} 12$ and C14, either improved (Storry et al., 1971) or had no effect (Hristov et al., 2009) on milk fat yield. The lack of milk fat response with SMCFA in the present study is in contrast to the findings observed in an earlier study where abomasal infusion of BF increased milk fat yield (Kadegowda et al., 2008).

Differences in the responses were more apparent when the transfer efficiency of individual SMCFA and mRNA abundance of lipogenic enzymes were considered. Kadegowda et al. (2008) reported apparent transfer efficiencies of $44 \%$ (C4), $0 \%$ (C6), $0 \%$ (C8), 33\% (C10), 67\% (C12), 83\% (C14), and 58\% (C16), respectively. In contrast, transfer efficiencies in the present study were much lower: $-2 \%(\mathrm{C} 4),-10 \%$ (C6), $-8 \%$ (C8), $-3 \%$ (C10), 22\% (C12), 52\% (C14), and $48 \%$ (C16). The higher transfer efficiency of individual SMCFA, along with greater mRNA abundance of lipogenic enzymes, including $A C C, F A S N, L P L, A G P A T$, and $D G A T$, might explain greater milk fat responses with BF infusion (Kadegowda, 2008). It is difficult to reconcile the differences between both studies. However, the cows used in the present study had higher average milk production (48 vs. $32 \mathrm{~kg} / \mathrm{d}$ ) and higher fat yields on the LCFA treatment (1,600 vs. 1,279 g/d), and likely a lower energy balance, as the cows were in an earlier stage of lactation. The higher energy requirements for lactation and reduced energy balance might have reduced the transfer efficiency of SMCFA by increasing its extramammary utilization, as SCFA can be absorbed directly from the digestive tract into the portal vein and can be preferentially oxidized in liver as energy substrates (Souza and Williamson, 1993).

\section{CONCLUSIONS}

Although CLA reduced mammary lipogenesis, the increased availability of SMCFA failed to rescue CLA- induced MFD. The milk fat responses with SMCFA were small and nonsignificant, with no effects observed on either mRNA or protein expression of lipogenic enzymes. The nutritional manipulation with intestinal SMCFA was insufficient to rescue CLA-induced MFD. This suggests that CLA-induced MFD is caused by more than just an insufficient supply of SMCFA, typically provided by de novo FA synthesis in the mammary gland.

\section{ACKNOWLEDGMENTS}

The authors thank Michael Dwyer and Brian Spielman at the Central Maryland Research and Education Center (CMREC, College Park, MD) for assistance with feeding, infusions, and conscientious care of experimental animals during this study.

\section{REFERENCES}

Barbano, D. M., and J. W. Sherbon. 1980. Poly-unsaturated protected lipid-Effect on triglyceride molecular-weight distribution. J. Dairy Sci. 63:731-740.

Bauman, D. E., and J. M. Griinari. 2003. Nutritional regulation of milk fat synthesis. Annu. Rev. Nutr. 23:203-227.

Baumgard, L. H., B. A. Corl, D. A. Dwyer, A. Saebø, and D. E. Bauman. 2000. Identification of the conjugated linoleic acid isomer that inhibits milk fat synthesis. Am. J. Physiol. Regul. Integr. Comp. Physiol. 278:R179-R184.

Baumgard, L. H., E. Matitashvili, B. A. Corl, D. A. Dwyer, and D. E. Bauman. 2002. trans-10, cis-12 conjugated linoleic acid decreases lipogenic rates and expression of genes involved in milk lipid synthesis in dairy cows. J. Dairy Sci. 85:2155-2163.

Bickerstaffe, R., and A. R. Johnson. 1972. The effect of intravenous infusions of sterculic acid on milk fat synthesis. Br. J. Nutr. $27: 561-570$.

Bionaz, M., and J. J. Loor. 2008. Gene networks driving bovine milk fat synthesis during the lactation cycle. BMC Genomics 9:366.

Bremmer, D. R., L. D. Ruppert, J. H. Clark, and J. K. Drackley. 1998. Effects of chain length and unsaturation of fatty acid mixtures infused into the abomasum of lactating dairy cows. J. Dairy Sci. 81:176-188.

Chouinard, P. Y., L. Corneau, A. Sæbb, and D. E. Bauman. 1999. Milk yield and composition during abomasal infusion of conjugated linoleic acids in dairy cows. J. Dairy Sci. 82:2737-2745.

Christensen, R. A., J. K. Drackley, D. W. LaCount, and J. H. Clark. 1994. Infusion of four long-chain fatty acid mixtures into the abomasum of lactating dairy cows. J. Dairy Sci. 77:1052-1069.

Christie, W. W. 1982. Lipid Analysis. 2nd ed. Pergamon Press Ltd., Oxford, UK.

Drackley, J. K., T. H. Klusmeyer, A. M. Trusk, and J. H. Clark. 1992. Infusion of long-chain fatty acids varying in saturation and chain length into the abomasum of lactating dairy cows. J. Dairy Sci. $75: 1517-1526$.

Gander, G. W., R. G. Jensen, and J. Sampugna. 1962. Analysis of milk fatty acids by gas-liquid chromatography. J. Dairy Sci. 45:323328.

Gervais, R., J. W. McFadden, A. J. Lengi, B. A. Corl, and P. Y. Chouinard. 2009. Effects of intravenous infusion of trans-10, cis-12 18: 2 on mammary lipid metabolism in lactating dairy cows. J. Dairy Sci. 92:5167-5177.

Harvatine, K. J., and D. E. Bauman. 2006. SREBP1 and thyroid hormone responsive spot 14 (S14) are involved in the regulation of bovine mammary lipid synthesis during diet-induced milk fat depression and treatment with CLA. J. Nutr. 136:2468-2474. 
Hristov, A. N., C. Lee, T. Cassidy, M. Long, K. Heyler, B. Corl, and R. Forster. 2011. Effects of lauric and myristic acids on ruminal fermentation, production, and milk fatty acid composition in lactating dairy cows. J. Dairy Sci. 94:382-395.

Hristov, A. N., M. V. Pol, M. Agle, S. Zaman, C. Schneider, P. Ndegwa, V. K. Vaddella, K. Johnson, K. J. Shingfield, and S. K. R. Karnati. 2009. Effect of lauric acid and coconut oil on ruminal fermentation, digestion, ammonia losses from manure, and milk fatty acid composition in lactating cows. J. Dairy Sci. 92:5561-5582.

Invernizzi, G., B. J. Thering, M. A. McGuire, G. Savoini, and J. J. Loor. 2010. Sustained upregulation of stearoyl-CoA desaturase in bovine mammary tissue with contrasting changes in milk fat synthesis and lipogenic gene networks caused by lipid supplements. Funct. Integr. Genomics 10:561-575.

Jensen, R. G. 2002. The composition of bovine milk lipids: January 1995 to December 2000. J. Dairy Sci. 85:295-350.

Kadegowda, A. K. G. 2008. Regulation of milk fat synthesis by dietary fatty acids. PhD Diss. University of Maryland, College Park. Accessed September 4, 2012. http://hdl.handle.net/1903/8363.

Kadegowda, A. K. G., M. Bionaz, L. S. Piperova, R. A. Erdman, and J. J. Loor. 2009. Peroxisome proliferator-activated receptor- $\gamma$ activation and long-chain fatty acids alter lipogenic gene networks in bovine mammary epithelial cells to various extents. J. Dairy Sci. $92: 4276-4289$.

Kadegowda, A. K. G., L. S. Piperova, P. Delmonte, and R. A. Erdman. 2008. Abomasal infusion of butterfat increases milk fat in lactating dairy cows. J. Dairy Sci. 91:2370-2379.

Laemmli, U. K. 1970. Cleavage of structural proteins during assembly of head of bacteriophage-T4. Nature 227:680-685.

Livak, K. J., and T. D. Schmittgen. 2001. Analysis of relative gene expression data using real-time quantitative PCR and the $2^{-\triangle \Delta \mathrm{CT}}$ method. Methods 25:402-408.

Loor, J. J., and J. H. Herbein. 2003. Reduced fatty acid synthesis and desaturation due to exogenous trans10, cis12-CLA in cows fed oleic or linoleic oil. J. Dairy Sci. 86:1354-1369.

Moore, J. H., and W. Steele. 1968. Dietary fat and milk fat secretion in cow. Proc. Nutr. Soc. 27:66-70.

NRC. 2001. Nutrient Requirements of Dairy Cattle. 7th rev. ed. Natl. Acad. Sci. Washington, DC.

Opstvedt, J., R. L. Baldwin, and M. Ronning. 1967. Effect of diet upon activities of several enzymes in abdominal adipose and mammary tissues in lactating dairy cow. J. Dairy Sci. 50:108-109.

Palmquist, D. L., and T. C. Jenkins. 1980. Fat in lactation rations: Review. J. Dairy Sci. 63:1-14.

Pégorier, J.-P., C. Le May, and J. Girard. 2004. Control of gene expression by fatty acids. J. Nutr. 134:2444S-2449S.

Peterson, D. G., E. A. Matitashvili, and D. E. Bauman. 2003. Diet-induced milk fat depression in dairy cows results in increased trans-10, cis-12 CLA in milk fat and coordinate suppression of mRNA abundance for mammary enzymes involved in milk fat synthesis. J. Nutr. 133:3098-3102.

Peterson, D. G., E. A. Matitashvili, and D. E. Bauman. 2004. The inhibitory effect of trans-10, cis-12 CLA on lipid synthesis in bovine mammary epithelial cells involves reduced proteolytic activation of the transcription factor SREBP-1. J. Nutr. 134:2523-2527.

Piperova, L. S., B. B. Teter, I. Bruckental, J. Sampugna, S. E. Mills, M. P. Yurawecz, J. Fritsche, K. Ku, and R. A. Erdman. 2000. Mammary lipogenic enzyme activity, trans fatty acids and conjugated linoleic acids are altered in lactating dairy cows fed a milk fat-depressing diet. J. Nutr. 130:2568-2574.

Rudolph, M. C., J. L. McManaman, T. Phang, T. Russell, D. J. Kominsky, N. J. Serkova, T. Stein, S. M. Anderson, and M. C. Neville. 2007. Metabolic regulation in the lactating mammary gland: A lipid synthesizing machine. Physiol. Genomics 28:323-336.

Rudolph, M. C., J. Monks, V. Burns, M. Phistry, R. Marians, M. R. Foote, D. E. Bauman, S. M. Anderson, and M. C. Neville. 2010. Sterol regulatory element binding protein and dietary lipid regulation of fatty acid synthesis in the mammary epithelium. Am. J. Physiol. Endocrinol. Metab. 299:E918-E927.

Souza, P. F. A., and D. H. Williamson. 1993. Effects of feeding medium-chain triacylglycerols on maternal lipid-metabolism and pup growth in lactating rats. Br. J. Nutr. 69:779-787.

Storry, J. E., A. J. Hall, and V. W. Johnson. 1971. Effects of increasing amounts of dietary coconut oil on milk-fat secretion in cow. J. Dairy Res. 38:73-77.

Storry, J. E., B. Tuckley, and A. J. Hall. 1969. Effects of intravenous infusions of triglycerides on secretion of milk fat in cow. Br. J. Nutr. 23:157-172.

Sutton, J. D. 1989. Altering milk-composition by feeding. J. Dairy Sci. 72:2801-2814.

Vogel, C., R. de Sousa Abreu, D. Ko, S.-Y. Le, B. A. Shapiro, S. C. Burns, D. Sandhu, D. R. Boutz, E. M. Marcotte, and L. O. Penalva. 2010. Sequence signatures and mRNA concentration can explain two-thirds of protein abundance variation in a human cell line. Mol. Syst. Biol. 6:400.

Vyas, D., B. B. Teter, and R. A. Erdman. 2012. Milk fat responses to dietary supplementation of short- and medium-chain fatty acids in lactating dairy cows. J. Dairy Sci. 95:5194-5202.

Woltman, T., D. Castellanos, and R. Reidelberger. 1995. Role of cholecystokinin in the anorexia produced by duodenal delivery of oleic acid in rats. Am. J. Physiol. 269:R1420-R1433.

Xu, H. E., M. H. Lambert, V. G. Montana, D. J. Parks, S. G. Blanchard, P. J. Brown, D. D. Sternbach, J. M. Lehmann, G. B. Wisely, T. M. Willson, S. A. Kliewer, and M. V. Milburn. 1999. Molecular recognition of fatty acids by peroxisome proliferatoractivated receptors. Mol. Cell 3:397-403. 